\title{
SOCIO-ECONOMIC DETERMINANTS OF ADOPTION OF IMPROVED MILLET PRODUCTION PRACTICES BY FARMERS IN BORNO STATE, NIGERIA
}

\author{
${ }^{*}$ Tijjani, H., ${ }^{1}$ Umar, B.F., ${ }^{2}$ Abubakar, B.Z. ${ }^{2}$ and Aliyu, U. ${ }^{3}$ \\ 1Department of Agricultural Technology, Ramat Polytechnic Maiduguri, Borno State. \\ 2Department of Agricultural Extension and Rural Development, Usmanu Danfodiyo University \\ Sokoto, Sokoto State. \\ 3Department of Crop Science, Usmanu Danfodiyo University Sokoto, Sokoto State.
}

*Corresponding e-mail: htijjani@gmail.com

\begin{abstract}
The study analyses the adoption of improved pearl millet production practices by farmers in Borno State, Nigeria. A multi-stage sampling technique was employed to select the sampled farmers. A structured questionnaire was used to interview 292 farmers across 30 villages in six Local Government Areas (LGAs) of two Agricultural Development Programme (ADP) zones. Descriptive and inferential statistics were used to analyse the data generated for the study. Findings on socioeconomic characteristics revealed that a greater proportion of both adopters and non-adopters were of the male gender, married and had farming as a major occupation. Results of ordered logistic regression suggested that farm size, farming experience, household size, extension contact, access to credit and awareness positively influenced adoption; whereas, age, annual income and cost of technology negatively influenced adoption. The most important problems associated with adoption of improved pearl millet production practices in the study area were unavailability of improved seeds, inaccessibility to farm credit and lack of extension support. Therefore, it is recommended that non-governmental organizations should complement government's effort in providing enabling environment for farmers to adopt improved practices through the provision of inputs such as improved seeds, fertilizer and agrochemicals. .
\end{abstract}

\section{Keywords: Adoption, Millet, Farmer, Production Practices.}




\section{INTRODUCTION}

Pearl millet (Pennisetum glaucum) is one of the four most important cereals grown in the tropics (The Syngenta Foundation for Sustainable Agriculture. SFSA, 2002) and the third major crop in Sub-Saharan Africa, with the major producing countries being Nigeria, Niger, Burkina Faso, Chad, Mali, Mauritania and Senegal in the west; Sudan and Uganda in the east. (Izge and Song, 2012). Besides providing feed for animal and food for humans, pearl millet straw is used for the construction of granaries, hut walls, fences and thatches, and the production of brooms, mats, baskets, sunshades, among others (International Funds for Agricultural Development. IFAD, 1999).

In developing countries like Nigeria, the benefits from adopting new technologies are viewed directly through productivity increases that can translate into higher farm incomes. Whereas, indirect benefits can accrue to other farmers and consumers through lower food prices, increase in food availability, accessibility and consumption and potentially non-farm employment (Ani, 2002; Ndjeunga et al., 2011).

A significant proportion of the farming population in Borno State still depends on the traditional practices of millet production despite the various improved millet production practices that are becoming available from research institutes such as the Lake Chad Research Institute (LCRI) and other related organizations. This ugly scenario calls for in-depth research to unravel and identify the inhibiting and facilitating factors to adoption of improved millet production practices in Borno State.

The main objective of the study was to determine factors influencing farmers' adoption of improved pearl millet production practices in Borno State, Nigeria. The specific objectives were to: (i) describe the socio-economic characteristics of pearl millet farmers in the study area; (ii) determine the factors influencing adoption of improved pearl millet production practices by farmers and to: (iii) identify the problems associated with adoption of improved pearl millet production practices in the study area.

\section{METHODOLOGY}

\section{Study Area}

The study was conducted in Borno State, which is located in the North-East of Nigeria. The State lies approximately between latitudes $10002 " \mathrm{~N}$ and $13004 " \mathrm{~N}$ and between longitudes $11004 \mathrm{E}$ and 14004"E (Folorunsho, 2006). It shares international boundaries with the Republic of Niger to the north, Chad to the north-east and Cameroon to the east. It also shares boundaries with Adamawa 
to the south, Yobe to the west and Gombe to the south-west. The state has an area of 69,435 square kilometers, about $7.69 \%$ of the total land area of the country and a population of $4,151,193$ with a density of approximately 60 inhabitants per square kilometer (National Population Commission. NPC, 2006). The state has 27 Local Government Areas (LGAs).

The climate of the area is characterized by dry and wet seasons. The wet season lasts from June to September in the north and May to October in the south while the dry season normally starts from November to April. The mean annual temperature is about $30^{\circ} \mathrm{C}$ with a maximum of $45^{\circ} \mathrm{C}$ in March and a Minimum of $15^{\circ} \mathrm{C}$ during the dry harmattan season. The annual rainfall ranges from $400 \mathrm{~mm}$ to $700 \mathrm{~mm}$ in the north and $500 \mathrm{~mm}$ to $900 \mathrm{~mm}$ in the southern part (Folorunsho, 2006).

Agriculture is the mainstay of the state's economy. The major crops grown include pearl millet, sorghum, cowpea, maize, groundnut, rice and soybean. Livestock and fisheries are also important agricultural activities in the State (Amaza et al., 2009).

\section{Sampling Technique}

Multi-stage sampling technique was used for the study. In the first stage, two Agricultural Development Programme (ADP) Zones (I and II) were purposively selected, being areas where pearl millet is predominantly grown. In the second stage, three LGAs were randomly selected from each of the two ADP Zones, making a total of six LGAs. In the third stage, five villages were randomly selected from each of the six LGAs, making a total of 30 villages. Thereafter, a total sample of 292 comprising 198 adopters and 94 nonadopters of pearl millet were drawn at $5 \%$ across the 30 villages.

\section{Sources of Data}

Both primary and secondary sources of information were used to generate data for the study. The primary data was generated through structured questionnaire while secondary information was obtained from journal publications and conference proceedings.

The analytical tools employed for the study include both descriptive and inferential statistics (Logistic regression). Adoption decisions can be analyzed with different binary choice models. Such models have been proposed for the analysis of dichotomous outcome variable. These include the linear probability function, logistic distribution function, and normal distribution function (Ameniya, 1981). These functions were used to approximate the mathematical relationships between explanatory variables and the adoption decision that is always assigned qualitative response variables (Gujarati, 1995).

The model is implicitly expressed as: 


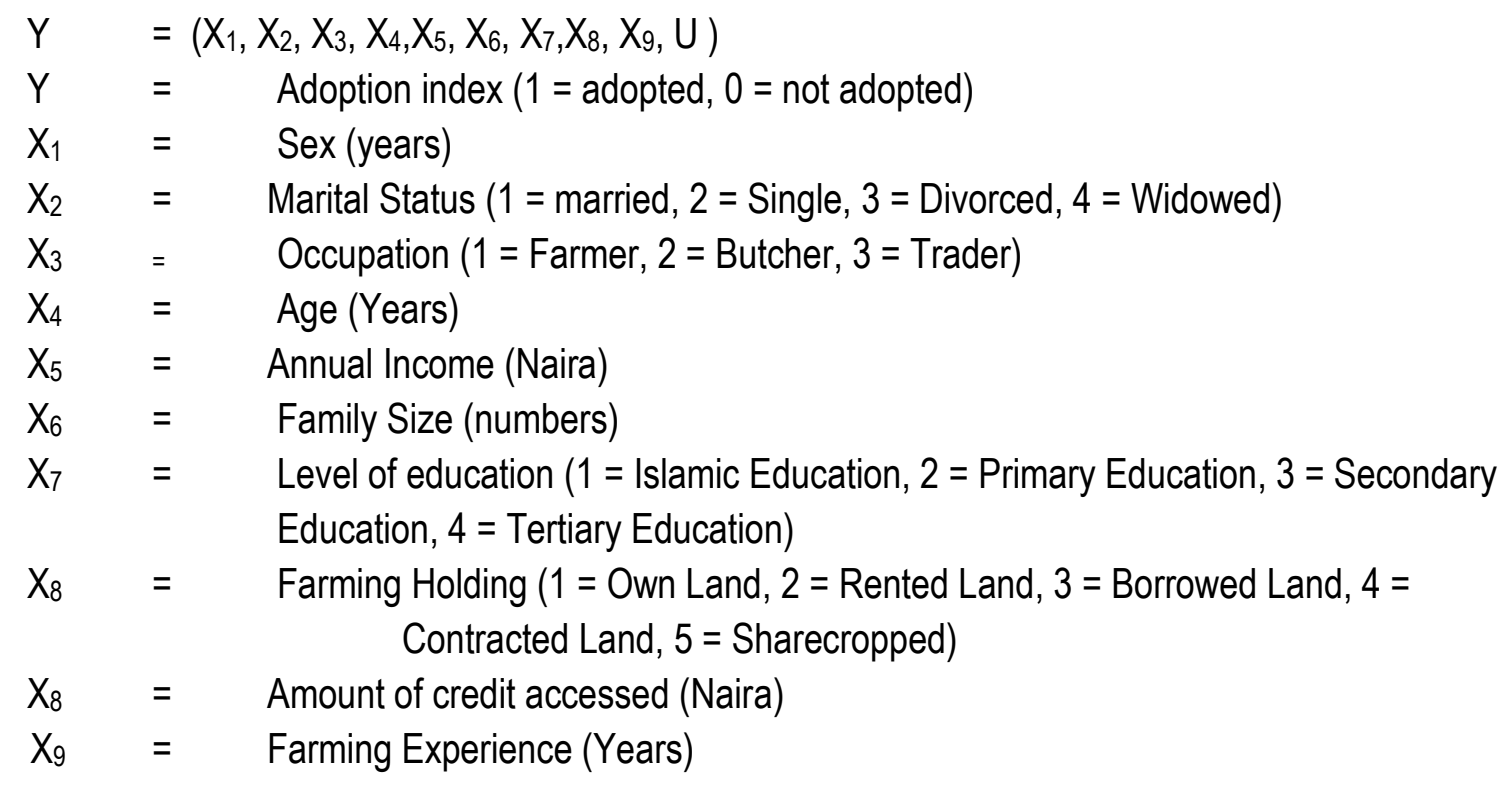

\section{RESULTS AND DISCUSSION}

\section{Socio-economic Characteristics of the Farmers}

Sex: Table 1 indicates that majority of the adopters (63.0\%) and non-adopters (67.0\%) were male, implying that most communities in the study area are traditionally patriarchal in nature.

Marital status: The findings also revealed that majority of adopters (76.0\%) and non-adopters $(54.2 \%)$ were married, while only $3.5 \%$ of the adopters were divorcees and $8.5 \%$ of non- adopters being widows suggesting that greater proportions of pearl millet farmers in the study area were married. This goes in line with Adebayo et al., (2018) that majority of maize farmers in Aiyedire LGA of Osun State were married.

Occupation: The findings also indicate that about $(69.7 \%)$ of the adopters engaged in farming as major occupation while $13 \%$ were butchers. Similarly, the majority (64.9\%) of the non-adopters were equally engaged in farming as major occupation with none being a civil servant. It suggests farming is the primary occupation of the people in the study area.

Age: About $38.9 \%$ of the adopters were within the age bracket of $36-43$ years with only $5.6 \%$ were above 65 years of age. Moreso, $46.8 \%$ of the non-adopters were between 56 and 65 years of age with $11.7 \%$ between 36 and 45 years of age implying that most of the adopters were younger than the non-adopters depicting the risk averse nature of the older and aged farmers 
who are usually more conservative than the younger ones. This result also lends support to the earlier findings of Anne et al., (2012) which indicated that the mean age of adopters was 49 years while it was 56 years for non-adopters.

Annual income: Income places farmers in good financial position to buy all the necessary inputs and adopt new agricultural technologies (Isah et al., 2010). A high proportion (59.1\%) of the adopters earned about 201,000 - $\$ 400,000$ in the last cropping season, while only $4.5 \%$ earned $\$ 801,000$ and above. Whereas, majority (77.7\%) of the non-adopters earned less than $\# 200,000$ while the remaining $22.3 \%$ earned between $\$ 201,000$ and $\$ 400,000$

Family size: Table 1 shows that $41.9 \%$ of the adopters had a family size of $6-10$ persons, while $6.6 \%$ had 16 and above. On the other hand, about (59.6\%) of the non-adopters had $11-15$ members per household and $4.3 \%$ had less than 5 members per household. This suggests that non adopters had larger family size than adopters in the study area.

Educational level: Results on table 1 shows that about $45.0 \%$ of the adopters had primary education, while majority $(50.0 \%)$ of the non-adopters had Islamic education. This implies that a higher proportion of the adopters had western education as against the non-adopters whose majority obtained Islamic education.

Land Holding: The results of the findings also shows that majority (65.2\%) of the adopters own land while $5.5 \%$ sharecropped land for pearl millet farming. On the other hand, majority $(73.4 \%)$ of the non-adopters also own land while only $6.4 \%$ borrowed land for pearl millet farming in the study area.

Farming experience: Table 1 further reveals that majority (52.0\%) of the adopters in the study area had 11 to 15 years of farming experience and $9.1 \%$ had less than 5 years of farming experience. Whereas, $41.5 \%$ of the non-adopters had over 10 years of faming experience and $8.5 \%$ had less than 5 years. This is consistent with Mahdi et al., (2012) who reported that non adopters are less experienced in farming than adopters. 
Table 1: Distribution of Farmers According to Socio economic Characteristics

\begin{tabular}{|c|c|c|c|c|c|c|}
\hline \multirow[t]{2}{*}{ Variable } & \multicolumn{2}{|c|}{ Adopters $\underline{\left(n_{1}=198\right)}$} & \multicolumn{2}{|c|}{ Non Adopters $\left(\mathrm{n}_{2}=94\right)$} & \multicolumn{2}{|c|}{ Total $(\mathbf{N}=292)$} \\
\hline & Frequency & Percentage & Frequency & Percentage & Frequency & Percentage \\
\hline \multicolumn{7}{|l|}{ Sex: } \\
\hline Male & 169 & 85.4 & 63 & 67.0 & 232 & 79.5 \\
\hline Female & 29 & 14.6 & 31 & 33.0 & 60 & 20.5 \\
\hline \multicolumn{7}{|l|}{ Marital } \\
\hline \multicolumn{7}{|l|}{ Status: } \\
\hline Single & 28 & 14.0 & 23 & 24.5 & 51 & 17.5 \\
\hline Married & 150 & 75.8 & 51 & 54.2 & 201 & 68.8 \\
\hline Divorced & 07 & 3.5 & 12 & 12.8 & 19 & 6.5 \\
\hline Widowed & 13 & 6.6 & 08 & 8.5 & 21 & 7.2 \\
\hline \multicolumn{7}{|l|}{ Occupatio } \\
\hline \multicolumn{7}{|l|}{$\mathrm{n}:$} \\
\hline Farming & 138 & 69.7 & 61 & 64.9 & 199 & 68.2 \\
\hline Butcher & 13 & 6.6 & 07 & 7.4 & 20 & 6.8 \\
\hline Trader & 27 & 13.6 & 26 & 27.7 & 53 & 18.2 \\
\hline Civil & 20 & 10.1 & 0 & 0 & 20 & 6.8 \\
\hline \multicolumn{7}{|l|}{ Service } \\
\hline \multicolumn{7}{|l|}{ Age } \\
\hline \multicolumn{7}{|l|}{ (years): } \\
\hline $18-35$ & 51 & 25.8 & 05 & 5.3 & 56 & 19.2 \\
\hline $36-45$ & 77 & 38.9 & 11 & 11.7 & 88 & 30.1 \\
\hline $46-55$ & 45 & 22.7 & 19 & 20.2 & 64 & 21.9 \\
\hline $56-65$ & 14 & 7.0 & 44 & 46.8 & 58 & 19.9 \\
\hline $\begin{array}{l}65 \text { and } \\
\text { above }\end{array}$ & 11 & 5.6 & 15 & 16.0 & 26 & 8.9 \\
\hline \multicolumn{7}{|l|}{ Annual } \\
\hline \multicolumn{7}{|l|}{ Income } \\
\hline \multicolumn{7}{|l|}{$(\$, 000):$} \\
\hline Less than & 35 & 17.7 & 73 & 77.7 & 108 & 37.1 \\
\hline 200 & & & & & & \\
\hline $201-400$ & 117 & 59.1 & 21 & 22.3 & 138 & 47.3 \\
\hline
\end{tabular}




\begin{tabular}{|c|c|c|c|c|c|c|}
\hline $401-600$ & 22 & 11.1 & 0 & 0 & 22 & 7.5 \\
\hline $601-800$ & 15 & 7.6 & 0 & 0 & 15 & 5.1 \\
\hline $\begin{array}{l}801 \text { and } \\
\text { above }\end{array}$ & 09 & 4.5 & 0 & 0 & 9 & 3.0 \\
\hline \multicolumn{7}{|l|}{ Family } \\
\hline \multicolumn{7}{|l|}{ Size: } \\
\hline Less than 5 & 62 & 31.3 & 04 & 4.3 & 66 & 22.6 \\
\hline $6-10$ & 83 & 41.9 & 16 & 17.0 & 99 & 33.9 \\
\hline $11-15$ & 40 & 20.2 & 56 & 59.6 & 96 & 32.9 \\
\hline $\begin{array}{l}16 \text { and } \\
\text { above }\end{array}$ & 13 & 6.6 & 18 & 19.1 & 31 & 10.6 \\
\hline Education & & & & & & \\
\hline $\begin{array}{l}\text { Level: } \\
\text { Islamic } \\
\text { Education }\end{array}$ & 60 & 30.0 & 47 & 50.0 & 107 & 36.7 \\
\hline $\begin{array}{l}\text { Primary } \\
\text { Education }\end{array}$ & 89 & 45.0 & 29 & 30.9 & 118 & 40.4 \\
\hline $\begin{array}{l}\text { Secondary } \\
\text { Education }\end{array}$ & 30 & 15.0 & 18 & 19.1 & 48 & 16.4 \\
\hline $\begin{array}{l}\text { Tertiary } \\
\text { Education } \\
\text { Land } \\
\text { Holding: }\end{array}$ & 19 & 10.0 & 0 & 0 & 19 & 6.5 \\
\hline Own Land & 129 & 65.2 & 69 & 73.4 & 198 & 67.8 \\
\hline $\begin{array}{l}\text { Rented } \\
\text { Land }\end{array}$ & 44 & 22.2 & 0 & 0 & 44 & 15.1 \\
\hline $\begin{array}{l}\text { Borrowed } \\
\text { Land }\end{array}$ & 11 & 5.6 & 06 & 6.4 & 17 & 5.8 \\
\hline $\begin{array}{l}\text { Contracted } \\
\text { Land }\end{array}$ & 03 & 1.5 & 0 & 0 & 03 & 1.0 \\
\hline $\begin{array}{l}\text { Share } \\
\text { cropped }\end{array}$ & 11 & 5.5 & 19 & 20.2 & 30 & 10.3 \\
\hline
\end{tabular}




\begin{tabular}{|c|c|c|c|c|c|c|}
\hline \\
\hline & $\begin{array}{l}\text { Experience: } \\
\text { Less than } 5 \quad 18 \\
\text { years }\end{array}$ \\
\hline \multicolumn{7}{|l|}{$\begin{array}{l}6-10 \\
\text { years }\end{array}$} \\
\hline $\begin{array}{l}11-15 \\
\text { years }\end{array}$ & 103 & 52.0 & 26 & 27.7 & 129 & 44.2 \\
\hline $\begin{array}{l}16 \text { years } \\
\text { and above }\end{array}$ & 43 & 21.7 & 39 & 41.5 & 82 & 28.1 \\
\hline
\end{tabular}

Source: Field Survey, 2012

\section{Determinants of Adoption of Improved Pearl Millet Production Practices}

Table 2 shows that the relationship between age and adoption of improved pearl millet production practices is statistically significant. The negative coefficient of the age variable suggests that the odds of adoption decreases by a factor of 0.97 for older farmers. Hence, adoption of improved pearl millet production practices was higher amongst young than old farmers. This is in harmony with the findings of Tijjani et al., (2018) which reported that age negatively influenced awareness of pesticide use practices among vegetable farmers in Jere LGA of Borno State.

Annual income of farmers was found to negatively and significantly influence the adoption of improved pearl millet production practices at $5 \%$ significance level. The negative coefficient of this variable suggests that the odds of adopting improved pearl millet production practices decreased by a factor of 0.10 . A possible explanation is that as farmers' income increases, they may engage in non-farm activities.

There is a positive relationship between farm size and adoption of improved pearl millet production practices. The coefficient is significant at $5 \%$ implying the odds in favour of adopting improved pearl millet production practices increased by a factor of 1.27 for farmers with large farms than those with smaller farms. This corroborates the findings of Tijjani et al., (2018) which suggests a positive relationship between awareness and farm size among farmers in Jere LGA of Borno State.

The results of the study further show that farming experience had positive influence on adoption of improved pearl millet production practices. This suggests that the likelihood of adoption increases with increase in farming experience of a farmer. Hence, the odds in favour of adopting improved pearl millet production practices increased by a factor of 1.14 for more experienced 
than less experienced farmers. However, this contradicts Awotide et al., (2013) who reported a negative relationship between farming experience and adoption of improved agricultural technology.

The findings indicate that household size of farmers had positively and significantly influenced adoption of improved pearl millet production practices at $10 \%$ significance level suggesting that the odds in favor of adopting improved pearl millet production practices are raised by a factor of 1.05 for farmers with larger households versus those with smaller households. This could be probably due to the fact that large family size is assumed as an indicator of labour availability in the family.

The results further indicate that extension contact had a positive and significant influence on adoption of improved pearl millet production practices. This suggests that the odds in favour of adopting improved pearl millet production practices increased by a factor of 1.07 for farmers with higher frequency of extension contacts compared to those with less contact. This is in tune with the findings of Odoemenem and Obinne (2010) who reported that extension contact had a positive coefficient.

There is a positive relationship between credit access and adoption of improved pearl millet production practices in the study area. This implies that the odds in favour of adopting improved practices increased by a factor of 1.00 for farmers who had access to credit than those without access. This agrees with Sisay et al., (2013) which reported a positive relationship between amount of credit received and adoption of modern beehives technology in Ethiopia.

The findings also indicate that total cost of technology has a significant but negative influence on adoption of improved pearl millet technology at $5 \%$ level. The negative coefficient implies that the odds for adopting the practices decreased by a factor of 0.88 . This indicates that for every increase in the cost of adopting the practices there is a corresponding decrease in the probability of adoption.

There is a positive relationship between awareness and adoption of improved pearl millet production practices. This agrees with the findings of Abdoulaye et al., (2014) which reported a positive relationship between awareness and adoption of improved cotton production practices in Katsina State. 
Table 2: Maximum Likelihood Estimates of Socio Economic Factors Influencing Adoption of Improved Pearl Millet Production Practices

\begin{tabular}{|c|c|c|c|c|c|c|}
\hline Variables & $\begin{array}{l}\text { Estimated } \\
\text { Parameters }\end{array}$ & Coefficients & $\begin{array}{l}\text { Odds } \\
\text { Ratio }\end{array}$ & $\begin{array}{l}\text { Standard } \\
\text { Errors }\end{array}$ & $\mathbf{Z}$ & P-Value \\
\hline Age & $X_{1}$ & -0.0288968 & 0.9715167 & 0.0135175 & -2.14 & $0.033^{* *}$ \\
\hline $\begin{array}{l}\text { Annual } \\
\text { income }\end{array}$ & $X_{2}$ & $-1.42 \mathrm{e}-06$ & 0.9999986 & $5.60 \mathrm{e}-07$ & -2.53 & $0.011^{* *}$ \\
\hline Farm size & $X_{3}$ & 0.2423498 & 1.27424 & 0.1158021 & 2.09 & $0.036^{* *}$ \\
\hline Education & $X_{4}$ & 0.0256419 & 1.025973 & 0.0278385 & 0.92 & $0.357 \mathrm{NS}$ \\
\hline $\begin{array}{l}\text { Farming } \\
\text { experience }\end{array}$ & $X_{5}$ & 0.128529 & 1.137154 & 0.0190203 & 6.76 & $0.000^{*}$ \\
\hline $\begin{array}{l}\text { Household } \\
\text { size }\end{array}$ & $X_{6}$ & 0.0525069 & 1.05391 & 0.0265442 & 1.98 & $0.048^{* *}$ \\
\hline $\begin{array}{l}\text { Extension } \\
\text { contact }\end{array}$ & $X_{7}$ & 0.066572 & 1.068838 & 0.0349841 & 1.90 & $0.057^{* * *}$ \\
\hline $\begin{array}{l}\text { Credit } \\
\text { access }\end{array}$ & $X_{8}$ & $4.36 \mathrm{e}-06$ & 1.000004 & $1.02 \mathrm{e}-06$ & 4.28 & $0.000^{*}$ \\
\hline $\begin{array}{l}\text { Cooperative } \\
\text { membership }\end{array}$ & $X_{9}$ & 0.0585657 & 1.060315 & 0.0823381 & 0.71 & $0.477^{\mathrm{NS}}$ \\
\hline Gender & $X_{10}$ & -0.1386958 & 0.8704928 & 0.369277 & -0.38 & $0.707^{\mathrm{NS}}$ \\
\hline $\begin{array}{l}\text { Cost of } \\
\text { technology }\end{array}$ & $X_{11}$ & -0.128496 & 0.8794171 & 0.0514786 & -2.50 & $0.013^{* *}$ \\
\hline Awareness & $X_{12}$ & 0.0000124 & 1.000012 & $2.59 \mathrm{e}-06$ & 4.80 & $0.000^{*}$ \\
\hline \multicolumn{7}{|c|}{ Log likelihood=-280.07082 } \\
\hline \multicolumn{7}{|c|}{$\operatorname{LRChi}^{2}(12)=189.22$} \\
\hline \multicolumn{7}{|c|}{ Prob > Chi ${ }^{2}=0.0000$} \\
\hline \multicolumn{7}{|c|}{ Pseudo R $=0.2525$} \\
\hline $\begin{array}{l}\text { Source: Field } \\
* \quad=\text { Signific } \\
* *=\text { Signific } \\
* * *=\text { Significd } \\
\text { NS }=\text { Not Sig }\end{array}$ & $\begin{array}{l}\text { Survey, } 2012 \\
\text { ant at } 1 \% \text { level } \\
\text { nt at } 5 \% \text { level } \\
\text { nt at } 10 \% \text { level } \\
\text { nificant at specif }\end{array}$ & ind houl 190 & & & & \\
\hline
\end{tabular}




\section{Problems Associated with Adoption of Improved Pearl Millet Production Practices}

Table 3 reveals that $42.2 \%$ of the adopters and $21.0 \%$ of the nonadopters of improved pearl millet practices posited that inaccessibility to improved seeds was one of the major constraints to the adoption of the practices in the study area. This suggests that lack of improved seeds could stifle the uptake of improved pearl millet production practices. This agrees with Yapi et al., (2006) who reported that lack of improved seeds ranked second with $67 \%$ in Mali.

The problems associated with adoption of improved pearl millet production practices in the adopter category indicated that inaccessibility to farm credit constituted $18.1 \%$, high cost of production $14.7 \%$, lack of enough extension support and lack of experience on improved pearl millet production practices constituted $13.4 \%$ and $11.3 \%$ respectively. However, in the nonadopter category, the findings show that $15.5 \%$ had problems in sourcing farm credit, $14.5 \%$ lacked experience on improved pearl millet production practices, $13.0 \%$ encountered high cost of production, and $19.0 \%$ had no awareness on improved pearl millet production practices. This finding suggests that all the adopters were aware of the practices while some of the non-adopter category were completely unaware of such practices. 


\section{Table 3: Distribution of Farmers Based on Problems Associated with Adoption of Improved Pearl Millet Production Practices}

\begin{tabular}{|c|c|c|c|c|c|c|}
\hline Variables & Adopters (n & $=198$ & Non Adopt & $\operatorname{rs}\left(\mathbf{n}_{2}=94\right)$ & Total $(N=$ & \\
\hline & Frequency & Percentage & Frequency & Percentage & Frequency & Percentage \\
\hline $\begin{array}{l}\text { Inaccessibility } \\
\text { to farm credit }\end{array}$ & $43^{*}$ & 18.1 & $31^{*}$ & 15.5 & 74 & 25.3 \\
\hline $\begin{array}{l}\text { Inaccessibility } \\
\text { to improved } \\
\text { seeds }\end{array}$ & $101^{*}$ & 42.4 & $42^{*}$ & 21.0 & 143 & 48.9 \\
\hline $\begin{array}{l}\text { Lack of } \\
\text { enough } \\
\text { extension } \\
\text { support }\end{array}$ & $32^{*}$ & 13.4 & $23^{*}$ & 11.5 & 55 & 18.8 \\
\hline $\begin{array}{l}\text { Lack of } \\
\text { experience }\end{array}$ & $27^{*}$ & 11.3 & $29^{*}$ & 14.5 & 56 & 19.2 \\
\hline $\begin{array}{l}\text { Low selling } \\
\text { price }\end{array}$ & 0 & 0 & $11^{*}$ & 5.5 & 11 & 3.8 \\
\hline $\begin{array}{l}\text { High cost of } \\
\text { production }\end{array}$ & $35^{*}$ & 14.7 & $26^{*}$ & 13.0 & 61 & 20.8 \\
\hline $\begin{array}{l}\text { Lack of } \\
\text { awareness }\end{array}$ & 0 & 0 & 28 & 19.0 & 28 & 9.6 \\
\hline
\end{tabular}

Source: Field Survey, 2012

*Multiple Response

\section{CONCLUSION AND RECOMMENDATIONS}

The study concludes that adopters of improved pearl millet production practices were younger in age, more educated, had smaller farm size and family size compared to the non- adopters. Socioeconomic variables such as family size, farming experience, household size, extension contact, access to credit, and awareness were found to positively influence adoption. Age, annual income, and cost of production negatively influenced the adoption of improved pearl millet production practices in the study area.

Based on the findings of the study, the following recommendations were made: 
1. Older farmers should be sensitized and encouraged to adopt improved pearl millet production practices.

2. Farmers with higher income should be encouraged to invest more in improved pearl millet production practices.

3. NGOs and other relevant stakeholders should be sensitized and encouraged to complement effort of the government through the provision of improved pearl millet seeds within farmers' access at affordable rate.

\section{REFERENCE}

Abdoulaye, T., Abbas, A., Maziya-Dixon, B., Tarawali, G., Okechukwu, R., Rusike, J., Alene, A., Manyong, V. and Ayedun, B. (2014). Awareness and Adoption of Improved Cassava Varieties and Processing Technologies in Nigeria. Journal of Development and Agricultural Economics. 6 (2): 67 - 75

Adebayo, S.A., Olorunfemi, D.O. and Odedoyin, C.B. (2018). Analysis of Maize Farmers' Access to Agricultural Information in Aiyedire Local Government Area, Osun State, Nigeria. Agrosearch 18 (1): 1 -14.

Amaza, P., Abdoulaye, T., Kwaghe, P. and Tagbaru, A. (2009). Changes in Household Food Security and Poverty Status in PROSAB Area of Southern Borno State, Nigeria. Promoting Sustainable Agriculture in Borno State (PROSAB). International Institute of Tropical Agriculture (IITA), Ibadan, Nigeria. 40

Amemiya, T. (1981). Qualitative Response Models: A Survey Journal of Economic Literature, 19 (4) 1483-1536.

Ani, A.O. (2002). Factors Inhibiting Agricultural Production Among Rural Women in Southern Ebonyi State, Nigeria. Ph.D. Thesis, (Unpublished) University of Maiduguri, Nigeria.

Anne, G.T., R.M. Mulwa, J. Okello, and M. Kamau (2012) The Role of Varietal Attributes on Adoption of Improved Seed Varieties. The Case of Sorghum in Kenya. Paper Presented at the Agricultural and Applied Economics Association's Annual Meeting, Seattle, Washington, August 12 - 14, 2012 
Awotide, B.A., A. Diagne and B.T. Omonona (2013). Impact of Improved Agricultural Technology Adoption on Sustainable Rice Productivity And Rural Farmers' Welfare in Nigeria: A Local Average Treatment Effect (LATE) Technique. Paper Presented At The African Economic Conference. October 30 - November 2. Kigali, Rwanda.

Folorunsho, O.A. (2006). Agricultural Development in Borno State: Problems and Prospects. An Invited Paper Delivered at the First Borno State Economic Summit held at International Conference Centre, Musa Usman Secretariat, Maiduguri, Nigeria. $6^{\text {th }}$ 11th May 2006. 17pp.

Gujarati, D.N. (1995). Basic Econometrics, 3 $3^{\text {rd }}$ Edition. Mc Graw-Hill, 568.

IFAD. (1999). International Funds for Agricultural Development. Farmer Participatory Testing of Technologies to Increase Sorghum and Pearl Millet Production in the Sahel. www.ifad.org/grants.

Izge, A.U. and I.M. Song (2012). Pearl Millet Breeding and Production in Nigeria: Problems and Prospects. Journal of Environmental Issues and Agriculture in Developing Countries. 5 (2): 25-33.

Jatto, N.A., M.A. Maikasuwa., A.Audu, and A.Alkali (2012) Assessment of Farmers' Understanding of the Information Displayed on Pesticide Product Labels in Ilorin Metropolis of Kwara State. Agrosearch 12 (1):107 - 166.

Mahdi, E., T. Pichai, R. Savitree, and T. Sayan (2012) Factors Affecting the Adoption of Improved Sorghum Varieties in Awbare District of Somali Regional State, Ethiopia. Kasetsart Journal of social sciences. 33:152 - 160

NPC (2006). National Population Commission (NPC), Population Census Data Borno State, Nigeria. Federal Republic of Nigeria Official Gazette, National and State Provisional Total Census. Printed and Published in 2007 by the Federal Government Printer, Lagos, Nigeria. 21 (94) 175- 198. 
Odoemenem, I.U. and C.P.O. Obinne (2010). Assessing the Factors Influencing the Utilization and Adoption of Improved Cereal Crop Production Technologies by Small-Scale Farmers in Nigeria. Indian Journal of Science and Technology. 3 (1) 0974-6846.

SFSA (2002). The Syngenta Foundation for Sustainable Agriculture Millet: Pearl Millet. http://syngentafoundation.org/whatispearlmillet.htm

Sisay,Y., M. Birham, and D. Melak (2013). Perception of Farmers Towards the use of Modern Beehives Technology in Ambara Region, Ethiopia. European Journal of Biological Sciences. 5 (1): 01 - 08

Tijjani, H., B.A. Tijjani and A. Audu (2018). Socio-economic Determinants of Vegetable Farmers' Awareness of Safety Measures in Pesticide use in Jere Local Government Area, Borno State, Nigeria. Agrosearch 18 (1) : 66 - 76 .

Yapi, A.M., A.O. Kergna, S.K. Debrah, A. Sidibe and O. Sango (2006). Analysis of the Economic Impact of Sorghum and Millet Research in Mali. Impact Series No 8. Patancheru 502324, Andhra Pradesh, India: International Crops Research Institute for the Semi-Arid Tropics. 60pp. ISBN 92-9066-419-3. Order code ISE 008. 